\title{
Nonlinear forcing of climate on mountain denudation during glaciations
}

\author{
Mariotti Apolline ${ }^{1,{ }^{*}}$, Blard Pierre-Henri 1, ${ }^{2}$, Charreau Julien ${ }^{1}$, Toucanne Samuel ${ }^{3}$, Jorry Stephan ${ }^{3}$,
} Molliex Stéphane ${ }^{1,4}$, Bourlès Didier L. ${ }^{5}$, Aumaître Georges ${ }^{5}$, Keddadouche Karim ${ }^{5}$

${ }^{1}$ CNRS, Université de Lorraine, CRPG, Nancy, France

2 Laboratoire de Glaciologie, DGES-IGEOS, Université Libre de Bruxelles, Bruxelles, Belgium

3 IFREMER, Laboratoire Géodynamique et Enregistrement Sédimentaire, Plouzané, France

${ }^{4}$ Laboratoire Géosciences Océan, Institut Universitaire Européen de la Mer, Plouzané, France

${ }^{5}$ Aix-Marseille Univ., CNRS, IRD, INRA, Coll. France, UM 34 CEREGE, Technopôle de

l'Environnement Arbois-Méditerranée, Aix-en-Provence, France

*Corresponding author : Apolline Mariotti, email address : apollinemariotti@gmail.com

\begin{abstract}
:
Denudation is one of the main processes that shapes landscapes. Because temperature, precipitation and glacial extents are key factors involved in denudation, climatic fluctuations are thought to exert a strong control on this parameter over geological timescales. However, the direct impacts of climatic variations on denudation remain controversial, particularly those involving the Quaternary glacial cycles in mountain environments. Here we measure in situ cosmogenic $10 \mathrm{Be}$ concentration in quartz in marine turbidites of two high-resolution cores collected in the Mediterranean Sea, providing a near-continuous (temporal resolution of $\sim 1-2 \mathrm{kyr}$ ) reconstruction of denudation in the Southern Alps since $75 \mathrm{kyr}$ ago (ka). This high-resolution palaeo-denudation record can be compared with well-constrained climatic variations over the last glacial cycle. Our results indicate that total denudation rates were approximately two times higher than present during the Last Glacial Maximum $(26.5-19 \mathrm{ka})$, the glacial component of the denudation rates being 1.5+0.9-1.0 mm yr-1. However, during moderately glaciated times (74-29 ka), denudation rates were similar to those today $(0.24 \pm 0.04 \mathrm{~mm} \mathrm{yr}-1)$. This suggests a nonlinear forcing of climate on denudation, mainly controlled by the interplay between glacier velocity and basin topography. Hence, the onset of Quaternary glaciations, 2.6 million years ago, did not necessarily induce a synchronous global denudation pulse.
\end{abstract}


23 timescales remains debated ${ }^{1,2}$. Relying on sedimentation records ${ }^{3}$ and thermochronology $\mathrm{y}^{4,5}$

24 several authors have reported increased denudation rates at the onset of Pleistocene

25 glaciations around 2.6 $\mathrm{Ma}^{6}$ either due to increased variability of Quaternary climatic $\mathrm{cycles}^{3}$ or 
1 growth of glaciers in mountain ranges, an efficient agent of erosion ${ }^{4,7}$. However, marine

${ }^{10} \mathrm{Be} /{ }^{9} \mathrm{Be}$ records indicate stable weathering rates over the same period ${ }^{1}$. Other studies have highlighted the potential biases inherent in sedimentary records ${ }^{8}$ and thermochronology ${ }^{9}$, and the link between weathering and erosion has also been questioned ${ }^{10}$. Moreover, the presence of glaciers does not necessarily lead to an increase in denudation rates ${ }^{11}$.

In-situ Terrestrial Cosmogenic Nuclides (TCNs) such as ${ }^{10} \mathrm{Be}$ record denudation rates in modern river systems ${ }^{12-14}$ as well as over geological $(10 \mathrm{Ma})$ timescales ${ }^{15,16}$. TCNs are not affected by the same biases as sedimentation rate estimates or thermochronology, and they track both weathering and erosion rates, i.e., denudation ${ }^{12-14}$, at sufficient resolution $(<1$ ka in better cases) to capture the impact of millennial climatic variations. Previous paleodenudation studies have used continental sedimentary archives such as cave sediments ${ }^{17,18}$, terrace deposits $^{19,20}$, lake sediments ${ }^{21,22}$ and molasse deposits in foreland basins ${ }^{15,16}$. However, these records are often too discontinuous to accurately reflect the impact of shortterm climatic variations on denudation. Additionally, the most complete records were obtained in active tectonic settings over long time scales ( $>5 \mathrm{Ma})$, making it difficult to decipher any climatic forcing ${ }^{15}$. Continuous, well-dated, and high-resolution marine sediment records in well-constrained sediment routing systems have great potential to overcome these limitations; they may represent the gold standard of TCN archives of paleo-denudation rates.

In this study, we measured in-situ ${ }^{10} \mathrm{Be}$ concentrations in 75-0 ka marine sediments exported by the Var River, which drains the Southern French Alps into the Mediterranean Sea (Fig. 1).

\section{Southern Alps, the reactive Var basin and samples}


Southern French Alps are a mountainous region that is considered tectonically stable since $75 \mathrm{ka}$, with near null horizontal and vertical motions ${ }^{25}$. The Var river catchment $(2,800$ $\mathrm{km}^{2}$, maximum altitude of 3,143 $\mathrm{m}$ above sea level, mean altitude of $1,250 \mathrm{~m}$ ) is a reactive watershed of this massif 26 , i.e., one that responds quickly to any change in denudation or sediment transport, with steep slopes (mean $\left.23^{\circ}\right)$ and a small alluvial plain $\left(<50 \mathrm{~km}^{2}\right)$ that limits on-land sediment storage ${ }^{24}$. The geology of the Var basin includes two main regions: the crystalline Mercantour-Argentera massif in the northern and highest part of the catchment, and sedimentary terrains in the southern part. Quartz-bearing rocks $\left({ }^{10} \mathrm{Be}\right.$ being measured in quartz) cover $26 \%$ of the Var watershed and are mainly present in the upper part of the catchment. The present-day ${ }^{10} \mathrm{Be}$-derived denudation rate of the entire Var catchment is 0.24 $\pm 0.04 \mathrm{~mm} \mathrm{a}^{-127}$. The mouth of the Var River is connected to a submarine canyon that incises both a virtually absent continental shelf (width $>200 \mathrm{~m}$ ) ${ }^{28}$ and a steep $\left(11^{\circ}\right.$ ) continental slope ${ }^{29}$. Hence, during the Quaternary, sediments draining the catchment have been continuously transferred to the deep depositional system of the Var in the form of turbidites, building the Var Sedimentary Ridge (VSR, $<2,000 \mathrm{~m}$ below sea level) ${ }^{28,29}$.

Due to a colder climate than today, the European Alps were extensively glaciated during Pleistocene (2.6 Ma to $11.7 \mathrm{ka}$ ) 23 . In the Var catchment, glaciers occupied the upper valleys of the Var, Tinée, and Vésubie Rivers (Fig. 1) during the Last Glacial Maximum²3 (LGM, 26.5-19 $\mathrm{ka}^{30}$ ). When the glaciers receded and completely melted most recently (19-11 ka), they left glacially polished surfaces ${ }^{31}$, and river incision began in the newly deglaciated valleys $^{32}$. This shift from glacial to fluvial environments is thought to have driven strong changes in denudation processes ${ }^{24,33}$. The high frequency of turbidites in the VSR is attributed to flood events, and their geochemical signatures $(\varepsilon N d)$ have been correlated to climatic changes in the Var basin, both over millennial Dansgaard-Oeschger cycles and glacial- 
1 interglacial periods 26,28 . This correlation is interpreted to have been driven by glacial fluctuations, as the highest sediment fluxes occurred during glacial maxima ${ }^{24}$.

A total of 26 samples of silts to fine sands (50-250 $\mu \mathrm{m})$ were collected from two cores drilled in the VSR (Fig. 2). ${ }^{10}$ Be concentrations in the samples range from $(0.91 \pm 0.12) \times 10^{4}$ at $\mathrm{g}^{-1}(19.8 \mathrm{ka}, \mathrm{LGM})$ to $(5.62 \pm 0.44) \times 10^{4}$ at $^{-1}\left(73.9 \mathrm{ka}\right.$, Marine Isotopic Stage (MIS) $\left.5 \mathrm{a}^{34}\right)$ (see Supp. Table 1 and 2, Methods, Supp. Section 1, Extended Data Fig. 1). Both DansgaardOeschger stadials and interstadials are documented by our sampling (Fig. 2a/b). Our data show that grain size has no impact on the ${ }^{10} \mathrm{Be}$ concentrations (see Methods, Supplementary Section 2). We analyzed 19 new samples (see Methods) to extend the coverage of pre-existing $\varepsilon N d$ data from $50-20 \mathrm{ka}^{24}$ to $74-50 \mathrm{ka}$ (Fig. 2c). Our new $\varepsilon N d$ values range between -10.3 and -9.6 (average -10.1).

\section{From ${ }^{10} \mathrm{Be}$ concentrations to paleo-denudation rates}

Deriving basin-wide denudation rates from ${ }^{10} \mathrm{Be}$ concentrations requires computing the ${ }^{10} \mathrm{Be}$ production rate at the time of sediment production. This parameter is mainly a function of basin altitude, which has likely remained steady over the last $75 \mathrm{ka} .{ }^{10} \mathrm{Be}$ production is also controlled by glacial extent because glaciers shield underlying rocks from cosmic rays, effectively eliminating ${ }^{10}$ Be production beneath several decameters of ice. To test the sensitivity of the glacial shielding on the denudation rates, we considered two scenarii to compute paleo-production rates ${ }^{36}$. The first assumes that no glaciers were present between 0 and 75 ka (Scenario 1: 'Ice-free'). Although this approach contradicts geomorphological evidence of glaciers in the Var catchment ${ }^{31,37}$, this endmember scenario provides maximum denudation rate estimates. In the second scenario (Scenario 2: 'Glaciated'), we computed paleo-production rates by reconstructing glacial extents. We used $\delta^{18} 0$ data from planktonic 
1 foraminifera ${ }^{26,28}$ sampled in both cores to compute sea surface paleo-temperatures, which we then used to reconstruct the glacial extents in the Var watershed using a simple 2D glacier flow model including a positive degree-day mass-balance ${ }^{38}$ (details in Supp. Section 3). The basin-averaged paleo-production rates were then calculated with the BASINGA code, assuming no cosmogenic production under ice ${ }^{36}$. Our modeling yields average glacial extents covering 21\%, 15\%, and 30\% of quartz-bearing rocks during MISs 4, 3, and LGM (19-26.5 ka), respectively. This glacial cover lowered production rates by $10 \%$ to $30 \%$ compared to the respective ice-free conditions (Supp. Table 4 and Extended Data Fig. 2 and 3).

The paleo-denudation rates (both scenarii) range between $0.15 \pm 0.01$ and $1.26 \pm 0.16$ $\mathrm{mm} \mathrm{a}^{-1}$ (all uncertainties are $1 \sigma$ ), implying ${ }^{10} \mathrm{Be}$ integration times of $0.5-3.9 \mathrm{ka}$ (see Methods), sufficiently short to observe the potential influence of major climatic changes both throughout the last glacial cycle and during the deglaciation. Moreover, with such integration times, potential inter-sample timescale biases are lower than 25\% ${ }^{39}$. Between 75 and 29 ka (MIS 5a3), both cosmogenic production models yield comparable and rather stable denudation rates between $0.15 \pm 0.01$ (Scenario 2, $73.9 \mathrm{ka}$ ) and $0.41 \pm 0.04 \mathrm{~mm} \mathrm{a}^{-1}$ (Scenario 1, $31.3 \mathrm{ka}$ ), with mean values of $0.32 \pm 0.03$ (Scenario 1) and $0.25 \pm 0.02 \mathrm{~mm} \mathrm{a}^{-1}$ (Scenario 2) (Fig. 2). These rates are similar to the present-day value of $0.24 \pm 0.04 \mathrm{~mm} \mathrm{a}^{-127}$.

\section{Potential causes of denudation variations}

The coldest event of MIS 4, corresponding to a 1 ka long episode according to the local $\delta^{18} \mathrm{O}(66-67 \mathrm{ka})($ Fig. $2 \mathrm{~b})$, did not decrease the ${ }^{10} \mathrm{Be}$ concentration. Additionally, neither climatic and glacial fluctuations reported in the Alps ${ }^{40,41}$ during MIS 4-3, nor Atlantic Dansgaard-Oeschger oscillations (well identified from $\delta^{18} 0$ records in the studied cores) had a noticeable impact on the ${ }^{10} \mathrm{Be}$ signal, suggesting that denudation rates are not significantly 
1 impacted by these millennial climatic variability ${ }^{1,33}$. The observed fluctuations in the turbidites frequency during MIS 4-3 (Fig. 2d) could thus reflect changing transport conditions in the sedimentary system rather than variations in denudation rates ${ }^{24}$. Nevertheless, $\varepsilon \mathrm{Nd}$ data indicate that partially glaciated valleys (Tinée and Vésubie) represented a significant contribution to the sedimentary supply between 75 and 20 ka (MIS 5a-2) (Fig. 2c).

Denudation rates obtained using both scenarii during MIS 2 and the LGM were more variable and on average two times higher than the present-day rate and those during MIS 4-3 (Fig. 2e, Extended Data Fig. 4). Indeed, the average ${ }^{10}$ Be concentrations of samples from the LGM are 50\% lower than those of MIS 4-3 and Holocene samples (see Supplementary Table 1). This period of lower ${ }^{10} \mathrm{Be}$ coincides with the largest glacial extent over the last $75 \mathrm{ka}$ : during the LGM (19-26.5 ka), glaciers covered nearly $30 \%$ of the quartz-bearing surfaces in the Var catchment (Extended Data Fig. 3). This drop in concentration could be due to contributions from ${ }^{10} \mathrm{Be}$-depleted sediments previously stored in the catchment. Such a mixing mechanism would lower the average ${ }^{10} \mathrm{Be}$ concentration, thus artificially enhancing denudation rates. A potential source of ${ }^{10} \mathrm{Be}$-depleted material is Pliocene sediments stored in the Var Canyon (mapped as Neogene-Quaternary near the outlet) (Fig. 1), whose incision may have been triggered by $\sim 40 \mathrm{~m}$ of sea level drop between the end of MIS 3 and MIS $2^{42}$. During warm ice-free periods, such as the Holocene, the $\varepsilon \mathrm{Nd}$ signature of the Var sediment is low $(-11$ to -10.5), indicating a lower contribution of radiogenic highland terrains (Fig. 2) ${ }^{24}$. Because Pliocene sediments were deposited during a warm and non-glaciated period, they are probably also characterized by low $\varepsilon N d$ value $(-11$ to -10.5$)$. Any reworking of these sediments during sea level drops should thus be associated with a drop in $\varepsilon N d$ values. The measured $\varepsilon N d$ values during the LGM (mean -10.1) are similar to the values measured during MIS 3-4, indicating that reworking of Pliocene sediments is unlikely. Another potential source 
1 of ${ }^{10} \mathrm{Be}-$ depleted materials could be paleo-moraines that accumulated on slopes during MIS 43. Assuming a steady denudation rate of $\sim 0.24 \mathrm{~mm} \mathrm{a}^{-1}$ during the LGM (similar to MIS 4-3 and present-day values ${ }^{27}$ ), a total of $\sim 1 \mathrm{~km}^{3}$ of sediments was produced over this 7.5 -ka-long period. The same volume of reworked MIS 4-3 moraine sediments would be required to lower the LGM ${ }^{10}$ Be concentrations by 50\% (see Supp. Section 4 and Extended Data Fig. 5 and 6). Assuming a simple triangular moraine shape, $1 \mathrm{~km}^{3}$ MIS 4-3 moraines would have been

When LGM glaciers intruded into lower valleys, they were probably able to increase bedrock incision and local denudation rates. The main mechanism here could be the basal velocity of the glaciers, that controls the denudation efficiency ${ }^{44}$ : by flowing into narrow valleys, LGM glaciers had higher local velocities that MIS 3-4 glaciers, and, hence, induced higher glacial incision ${ }^{44,45}$ (Fig. 3).

After a lag time of few thousand years necessary to remove the first meters of the ${ }^{10} \mathrm{Be}-$ rich fluvial landscape soil, the glacial incision then delivered shielded material to the system. After mixing with the fluvial sediments in the lower part of the watershed, this glacial input induced a drop in ${ }^{10} \mathrm{Be}$ concentrations.

\section{Such denudation solely due to the glacial incision can be quantified using a mass} balance approach, which assumes that the ${ }^{10}$ Be concentration measured in each sample is a mix of glacial and fluvial contributions ${ }^{46}$ (see Supp. Section 5). The resulting average glacial 
1 erosion rate during the LGM is $1.5_{-1.0}^{+0.9} \mathrm{~mm} \mathrm{a}^{-1}$, roughly four times above the value of $0.4_{-0.5}^{+0.4}$ obtained during MIS 4-3 (Figs. 2, 3, Extended Data Fig. 7 and 8). This LGM glacial denudation is similar to the maximum local glacial incision estimated in the upper Tinée during MIS 5d-2 $\left(1.8 \mathrm{~mm} \mathrm{a}^{-1}\right)^{31}$, and to the value proposed for present-day small temperate glaciers in the Swiss Alps $\left(1 \mathrm{~mm} \mathrm{a}^{-1}\right)^{7}$. At such incision rates, glacial incision requires 2 to 4 kyrs to reach substratum with null ${ }^{10} \mathrm{Be}$ concentration. This is consistent with the observation that ${ }^{10} \mathrm{Be}$ dropped after $25 \mathrm{ka}, \sim 4 \mathrm{kyr}$ after the onset of the cold conditions of MIS 2 (Fig. 2).

During MIS 4-3, between 75 and 26.5 ka, glaciers existed but were likely restricted most of the time to the highest parts of the catchment, in cirques and hanging valleys, with a low erosive power ${ }^{45}$ (Extended Data Fig. 9). Only for $\sim 1$ ka during the MIS 4 glaciers possibly reached the lower valley as during the LGM (according to the local $\delta^{18} 0$ curve (Fig. 2b)). However, this glacial advance was likely too short to significantly carve the landscape and deeply erode the bedrock to produce ${ }^{10}$ Be depleted sediments. During the LGM, the advance of glaciers in deep valleys likely increased denudation during $7 \mathrm{ka}$. Along with the reworking of MIS 4-3 moraines, this contributed to lowering the ${ }^{10} \mathrm{Be}$ concentrations and increasing the overall denudation rates of the Var basin (Figs. 2e, 3).

(1)

19

During deglaciation (19-11 ka) ${ }^{37}$, the overall ${ }^{10}$ Be-denudation rates dropped, becoming close to the present-day value (Fig. 2e). The denudation decrease between 19 and $15 \mathrm{ka}$ is concomitant with the $\varepsilon \mathrm{Nd}$-inferred shift of sediment sources from exposed crystalline massifs to sedimentary cover (Fig. 2c), and with a decrease in riverine sediment inputs (Fig. $2 d)^{26}$. These changes suggest that denudation dynamics returned to fluvial conditions during that time $\mathrm{e}^{24}$. At $10 \mathrm{ka}$, we observe a spike in denudation rates synchronous with a positive $\varepsilon \mathrm{Nd}$ excursion (Fig. 2e). This short-term ${ }^{10}$ Be spike is only supported by one core sample and 
occurred during a period of increased rainfall in the Mediterranean region ${ }^{47}$. Together with the $\varepsilon \mathrm{Nd}$ spike, this excursion is characteristic of a paraglacial lag in the sedimentary transport of previously eroded glacial sediments ${ }^{48}$ and should not be considered as an actual increase in bedrock denudation ${ }^{24}$. After this spike, Holocene denudation rates are similar to present-day rates and those observed during MIS 4-3 (Figs. 2, 3).

Our 75-ka-long denudation record from the Southern French Alps indicates a nonlinear link between climate and denudation, as shown by the relationship between $\delta^{18} \mathrm{O}$-derived sea surface temperatures and ${ }^{10} \mathrm{Be}$-derived denudation rates (Fig. 4).

\section{Implications for other regions and climatic periods}

Our data suggest that climatic variations may only strongly affect denudation beyond a certain threshold, probably controlled by the glacier dynamics ${ }^{44,45}$, the duration of glacial advances and temperature driven processes (e.g. frost cracking) ${ }^{49,50}$. Since the denudation is enhanced during the LGM period, when glacier advanced and carved deep U-shaped narrow valleys, basal ice velocity was probably the main driver of this non-linear response. This mechanism was suggested for present-day ${ }^{44}$ and at million years timescale ${ }^{18}$, and our study is the first to detect such behaviour at the glacial-interglacial timescale.

In conclusion, our study indicates that the denudation response to Quaternary glaciations is complex and non-linear in glaciated areas. This result has strong and broad implications for the erosion dynamics: climatic variations affect denudations on the glacialinterglacial timescales in a non-linear way, basin topography and duration of glacial advances being major forcings. Since glacier dynamics are nonlinearly controlled by climate and topography, climatic impacts on denudation in glaciated regions may thus be spatiotemporally variable. Therefore, our study suggests that, in glaciated regions, the 
1 response of the landscapes to the onset of Quaternary glaciation is not necessarily a

2 synchronous global pulse ${ }^{3}$.

3

4

5

6

7

8

9

10

11

12

13

14

15

16

17

18

19

20

21

22

23

24

25

26

27 


\section{REFERENCES}

1. Willenbring, J. K. \& Jerolmack, D. J. The null hypothesis: globally steady rates of erosion, weathering fluxes and shelf sediment accumulation during Late Cenozoic mountain uplift and glaciation. Terra Nov. 28, 11-18 (2016).

2. Herman, F. \& Champagnac, J.-D. Plio-Pleistocene increase of erosion rates in mountain belts in response to climate change. Terra Nov. 28, 2-10 (2016).

3. Peizhen, Z. et al. Increased sedimentation rates and grain sizes 2-4 Myr ago due to the influence of climate change on erosion rates. Nature 410, 891-897 (2001).

4. Herman, F. et al. Worldwide acceleration of mountain erosion under a cooling climate. Nature 504, 423-426 (2013).

5. Valla, P. G., Shuster, D. L. \& Van Der Beek, P. A. Significant increase in relief of the European Alps during mid-Pleistocene glaciations. Nat. Geosci. 4, 688-692 (2011).

6. Batchelor, C. L. et al. The configuration of Northern Hemisphere ice sheets through the Quaternary. Nat. Commun. 10, 3713 (2019).

7. Hallet, B., Hunter, L. \& Bogen, J. Rates of erosion and sediment evacuation by glaciers: A review of field data and their implications. Glob. Planet. Change 12, 213-235 (1996).

8. Sadler, P. M. \& Jerolmack, D. J. Scaling laws for aggradation, denudation and progradation rates: the case for time-scale invariance at sediment sources and sinks. Geol. Soc. London, Spec. Publ. 404, 69-88 (2015).

9. Schildgen, T. F., Van Der Beek, P. A., Sinclair, H. D. \& Thiede, R. C. Spatial correlation bias in late-Cenozoic erosion histories derived from thermochronology. Nature 559, 89-93 (2018).

10. Norton, K. P. \& Schlunegger, F. Lack of a weathering signal with increased Cenozoic erosion? Terra Nov. 29, 1-8 (2017). 
1 11. Thomson, S. N. et al. Glaciation as a destructive and constructive control on mountain building. Nature 467, 313-317 (2010).

12. Brown, E. T., Stallard, R. F., Larsen, M. C., Raisbeck, G. M. \& Yiou, F. Denudation rates determined from the accumulation of in situ-produced 10Be in the luquillo experimental

5 forest, Puerto Rico. Earth Planet. Sci. Lett. 129, 193-202 (1995).

13. Bierman, P. R. \& Steig, E. J. Estimating rates of denudation using cosmogenic isotope abundances in sediment. Earth Surface Processes and Landforms 21, 125-139 (1996).

14. Granger, D. E., Kirchner, J. W. \& Finkel, R. C. Spatially Averaged Long-Term Erosion Rates Measured from in Situ-Produced Cosmogenic Nuclides in Alluvial Sediment. J. Geol. 104, 249-257 (1996).

15. Puchol, N. et al. Limited impact of Quaternary glaciations on denudation rates in Central Asia. Geol. Soc. Am. Bull. 129, 479-499 (2017).

16. Charreau, J. et al. Paleo-erosion rates in Central Asia since 9Ma: A transient increase at the onset of Quaternary glaciations? Earth Planet. Sci. Lett. 304, 85-92 (2011).

17. Anthony, D. M. \& Granger, D. E. A new chronology for the age of Appalachian erosional surfaces determined by cosmogenic nuclides in cave sediments. Earth Surf. Process. Landforms 32, 874-887 (2007).

18. Haeuselmann, P., Granger, D. E., Jeannin, P.-Y. \& Lauritzen, S.-E. Abrupt glacial valley incision at 0.8 Ma dated from cave deposits in Switzerland. Geology 35, 143 (2007).

19. Schaller, M. et al. A $30000 \mathrm{yr}$ record of erosion rates from cosmogenic 10Be in Middle European river terraces. Earth Planet. Sci. Lett. 204, 307-320 (2002).

20. Bekaddour, T. et al. Paleo erosion rates and climate shifts recorded by Quaternary cutand-fill sequences in the Pisco valley, central Peru. Earth Planet. Sci. Lett. 390, 103-115 (2014). 
1 21. Marshall, J. A., Roering, J. J., Gavin, D. G. \& Granger, D. E. Late Quaternary climatic

controls on erosion rates and geomorphic processes in western Oregon, USA. Geol. Soc. Am. Bull. 129, 715-731 (2017).

22. Grischott, R. et al. Millennial scale variability of denudation rates for the last $15 \mathrm{kyr}$ inferred from the detrital 10 Be record of Lake Stappitz in the Hohe Tauern massif, Austrian Alps. The Holocene 27, 1914-1927 (2017).

23. Ehlers, J., Gibbard, P. L. \& Hughes, P. D. Quaternary Glaciations - Extent and Chronology A Closer Look : part I: Europe. (Elsevier Ltd., 2011).

24. Bonneau, L. et al. Glacial erosion dynamics in a small mountainous watershed (Southern French Alps): A source-to-sink approach. Earth Planet. Sci. Lett. 458, 366-379 (2017).

25. Nocquet, J.-M. et al. Present-day uplift of the western Alps. Sci. Rep. 6, 28404 (2016).

26. Bonneau, L., Jorry, S. J., Toucanne, S., Silva Jacinto, R. \& Emmanuel, L. Millennial-Scale Response of a Western Mediterranean River to Late Quaternary Climate Changes: A View from the Deep Sea. J. Geol. 122, 687-703 (2014).

27. Mariotti, A., Blard, P.-H., Charreau, J., Petit, C. \& Molliex, S. Denudation systematics inferred from in situ cosmogenic 10Be concentrations in fine (50-100 $\mu \mathrm{m}$ ) and medium (100-250 $\mu \mathrm{m}$ ) sediments of the Var River basin, southern French Alps. Earth Surf. Dyn. 7, 1059-1074 (2019).

28. Jorry, S. J., Jégou, I., Emmanuel, L., Silva Jacinto, R. \& Savoye, B. Turbiditic levee deposition in response to climate changes: The Var Sedimentary Ridge (Ligurian Sea). Mar. Geol. 279, 148-161 (2011).

29. Savoye, B., Piper, D. J. W. \& Droz, L. Plio-Pleistocene evolution of the Var deep-sea fan off the French Riviera. Mar. Pet. Geol. 10, 550-571 (1993).

30. Clark, P. U. et al. The Last Glacial Maximum. Science (80-. ). 325, 710-714 (2009). 
1 31. Darnault, R. et al. Timing of the last deglaciation revealed by receding glaciers at the

2 Alpine-scale: impact on mountain geomorphology. Quat. Sci. Rev. 31, 127-142 (2012).

3 32. Petit, C. et al. Recent, climate-driven river incision rate fluctuations in the Mercantour

4 crystalline massif, southern French Alps. Quat. Sci. Rev. 165, 73-87 (2017).

33. Koppes, M. \& Montgomery, D. R. The relative efficacy of fluvial and glacial erosion over modern to orogenic timescales. Nat. Geosci. 2, 644-647 (2009).

34. Railsback, L. B., Gibbard, P. L., Head, M. J., Voarintsoa, N. R. G. \& Toucanne, S. An optimized scheme of lettered marine isotope substages for the last 1.0 million years, and the climatostratigraphic nature of isotope stages and substages. Quat. Sci. Rev. 111, 94-106 (2015).

35. Andersen, K. K. et al. High-resolution record of Northern Hemisphere climate extending into the last interglacial period. Nature 431, 147-151 (2004).

36. Charreau, J. et al. Basinga: A cell - by - cell GIS toolbox for computing basin average scaling factors, cosmogenic production rates and denudation rates. Earth Surf. Process. Landforms 44, 2349-2365 (2019).

37. Rolland, Y. et al. Deglaciation history at the Alpine - Mediterranean transition (Argentera - Mercantour, SW Alps) from 10 Be dating of moraines and glacially polished bedrock. Earth Surf. Process. Landforms 45, 393-410 (2020).

38. Harper, J. T. \& Humphrey, N. F. High altitude Himalayan climate inferred from glacial ice flux. Geophys. Res. Lett. 30, 3-6 (2003).

39. Ganti, V. et al. Time scale bias in erosion rates of glaciated landscapes. Sci. Adv. 2, e1600204-e1600204 (2016).

40. Heiri, O. et al. Palaeoclimate records 60-8 ka in the Austrian and Swiss Alps and their forelands. Quat. Sci. Rev. 106, 186-205 (2014). 
1 41. Ivy-Ochs, S. et al. Chronology of the last glacial cycle in the European Alps. J. Quat. Sci. 23, 559-573 (2008).

42. Waelbroeck, C. et al. Sea-level and deep water temperature changes derived from benthic foraminifera isotopic records. Quat. Sci. Rev. 21, 295-305 (2002).

43. Federici, P. R. et al. Last Glacial Maximum and the Gschnitz stadial in the Maritime Alps according to 10Be cosmogenic dating. Boreas 41, 277-291 (2012).

44. Herman, F. et al. Erosion by an Alpine glacier. Science (80-. ). 350, 193-195 (2015).

45. Brædstrup, C. F., Egholm, D. L., Ugelvig, S. V. \& Pedersen, V. K. Basal shear stress under alpine glaciers: insights from experiments using the iSOSIA and Elmer/Ice models. Earth Surf. Dyn. 4, 159-174 (2016).

46. Guillon, H. et al. Improved discrimination of subglacial and periglacial erosion using10Be concentration measurements in subglacial and supraglacial sediment load of the Bossons glacier (Mont Blanc massif, France). Earth Surf. Process. Landforms 40, 1202-1215 (2015).

47. Toucanne, S. et al. Tracking rainfall in the northern Mediterranean borderlands during sapropel deposition. Quat. Sci. Rev. 129, 178-195 (2015).

48. Church, M. \& Ryder, J. Paraglacial Sedimentation: A Consideration of Fluvial Processes Conditioned by Glaciation. Bull. Geol. Soc. Am. 83, 319-342 (1972).

49. Delunel, R., Van Der Beek, P. A., Carcaillet, J., Bourlès, D. L. \& Valla, P. G. Frost-cracking control on catchment denudation rates: Insights from in situ produced 10Be concentrations in stream sediments (Ecrins-Pelvoux massif, French Western Alps). Earth Planet. Sci. Lett. 293, $72-83$ (2010).

50. Egholm, D. L., Andersen, J. L., Knudsen, M. F., Jansen, J. D. \& Nielsen, S. B. The periglacial engine of mountain erosion - Part 2: Modelling large-scale landscape evolution. Earth Surf. Dyn. 3, 463-482 (2015). 


\section{CORRESPONDING AUTHOR}

Correspondence and request for material should be addressed to A.M.

4 (apollinemariotti@gmail.com)

\section{ACKNOWLEDGEMENTS}

This research was funded by the ANR JC EroMed project ( ${ }^{\circ}$ ANR-17-CE01-0011-01; Principal Investigator P.-H. Blard). This work is part of the PhD thesis of Apolline Mariotti, whose scholarship was jointly supported by the CNRS and the Région Grand Est. The ASTER AMS national facility (CEREGE, Aix en Provence) is supported by the INSU/CNRS, the ANR through the "Projets thématiques d'excellence" program for the "Equipements d'excellence" ASTER CEREGE action and IRD. Fruitful discussions with Carole Petit, Vincent Godard and Lucille Bonneau benefited the design of the study and interpretation of the results. We are grateful to Laëticia Léanni and Régis Braucher for their expertise in ${ }^{10}$ Be wet chemistry at LN2C/CEREGE and to Anne Trinquier at IFREMER for the Nd measurements. Robert Dennen is acknowledged for proofreading and improving the overall readability of the manuscript.

\section{AUTHOR CONTRIBUTIONS}

A.M., P.-H.B., S.T., J.C. and S.J.J designed the study. P.-H.B, S.T., S.M., and A.M. collected the samples for analysis. A.M. prepared the samples for ${ }^{10} \mathrm{Be}$ and $\mathrm{Nd}$ analysis. D.B, G.A and K.K. measured the ${ }^{10} \mathrm{Be} /{ }^{9} \mathrm{Be}$ ratios using the French Service National AMS ASTER. A.M., P.-H.B., J.C., S.T. and S.M., analyzed the data. AM wrote the initial manuscript, all authors commented and contributed to the final version.

\section{COMPETING INTERESTS STATEMENT}


The authors declare that they have no conflict of interest.

\section{FIGURE CAPTIONS}

Fig. 1 | The Var watershed and sedimentary system. Geological data is from the French Geological Survey and bathymetry from the EMODnet Bathymetry Consortium (references provided in the Methods). Last Glacial Maximum (LGM) glacial extent based on Ehlers et al., $(2011)^{23}$, and $\varepsilon N d$ sampling points from Bonneau et al., (2017) ${ }^{24}$. Sampling sites of cores ESSK08-CS01 and ESSK08-CS13 are shown in the Var Sedimentary Ridge.

Fig. 2 | Climate, sediment provenance, and flood proxies compared to denudation rates. a The high-resolution $\delta^{18} 0$ record of Greenland ice core NGRIP (a proxy of climate) ${ }^{35}$. Numbers and labels indicate D-O events. b $\delta^{18} 0$ values of $G$. bulloides (a local proxy of sea surface temperature) and ${ }^{14} \mathrm{C}$ control points from the studied cores ${ }^{24,26,28 .}$ Point colours indicate the core (data in Supp. Table S2). c eND data from the ESSK08-CS01 and ESSK0-CS13 cores, reflecting sediment provenance. The most recent data (since $\sim 50 \mathrm{ka}$ ) are from Bonneau et al. ${ }^{24}$, and the points labeled "this study" are new data. The orange shaded area corresponds to $2 \sigma$ uncertainties (data in Supp Table S3). d Mean turbidite fluxes over the two cores ${ }^{26}$. e ${ }^{10} \mathrm{Be}$-derived denudation rates according to the ice-free and glaciated scenarii (Scenarii 1 and 2, respectively. Data in Supp. Table S4). Colored squares adjacent to the data points indicate

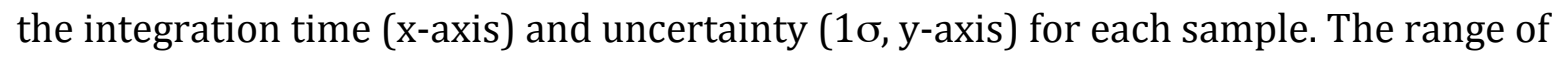
present-day values is from Mariotti et al. ${ }^{27}$, and the LGM is from Clark et al. ${ }^{30}$. Purely glacial erosion rates were calculated by mass balance, accounting only for erosion in glaciated areas (i.e., excluding fluvial contributions to the denudation rate; see text and Supplementary Information, data in Supp. Table S5). 
Fig. 3 | Schematic representations of denudation dynamics in the Var watershed.

Denudation was calculated according to the glaciated scenario (see Methods and Supp Info) in the Var watershed. a MIS 4-3 (71-29 ka). b the Last Glacial Maximum (LGM, 26.5-19 ka). c present day ${ }^{27}$. For MIS 3-4 and LGM, $\varepsilon_{\mathrm{G}}$ values represent purely glacial denudation (i.e., without any contribution from fluvial processes), and were estimated using variable ${ }^{10} \mathrm{Be}$ concentrations in glaciated areas (see Methods). $\varepsilon_{\text {mix }}$ values are weighted means of the catchment-wide (glacial and fluvial) denudation rates. $\varepsilon_{\mathrm{F}}$ is the present-day catchment-wide (fluvial) denudation rate ${ }^{27}$. All uncertainties are $1 \sigma$. In the upper part of the catchment, orange arrows indicate slow glacial flow and limited glacial erosion. In distal narrow valleys downstream, red arrows indicate high flow glacial velocity and high subglacial denudation rates.

Fig. 1 | Comparison of denudation rates and sea surface temperature proxy data. ${ }^{10} \mathrm{Be}-$ derived denudation rates as a function of $\mathrm{d}^{18} \mathrm{O}$ values measured in the cores, according to the two scenarii used to convert ${ }^{10} \mathrm{Be}$ concentrations to denudation rates (see Methods). Uncertainties on the denudation rates correspond to 1s. Although there is no clear relationship between the two parameters, higher denudation rates only occur for $\boldsymbol{\delta}^{18} 0$ values higher than $3.5 \%$.

\section{METHODS}

\section{Cores and samples}

We sampled sediments (Supplementary Table 1) from two Calypso piston cores collected in $2008^{51}$ (Fig. 1): ESSK08-CS01 (22 m long) is from the VSR levee crest (2,146 m water depth) and ESSK01-CS13 (24 m long) from the southwestern flank of the VSR (2,473 m water depth). 
1 Age models for both cores were previously anchored by $25^{14} \mathrm{C}$ dates, as well as highresolution planktonic oxygen isotope stratigraphy ${ }^{26,28}$ (Fig. 2a, b, Supplementary Table 2). Accordingly, core ESSK08-CS01 spans 0.3-29.8 ka and ESSK08-CS13 spans 0.5-74.2 ka, corresponding to mean sedimentation rates of 80 and $30 \mathrm{~cm} \mathrm{ka}^{-1}$, respectively.

Twenty-six samples (19 in ESSK01-CS13 and 4 in ESSK08-CS01) were selected from coarser $(>50 \mu \mathrm{m})$ turbiditic facies suitable for in-situ ${ }^{10} \mathrm{Be}$ analyses in quartz ${ }^{27}$. Because of the reactive nature of the watershed and the depth of the VSR, all samples were buried quickly and have not been re-exposed to cosmic radiation: changes in ${ }^{10} \mathrm{Be}$ concentrations thus reflect only denudation rate variations. Sample preparation and analytical methods are described in the Supplementary Information.

\section{Computation of ${ }^{10} \mathrm{Be}$-derived denudation rates}

Basin-averaged denudation rates were calculated using a simplified version of Eq. 1 of Brown'12:

$\bar{\varepsilon}=\frac{1}{\rho} \sum_{i, x} \frac{\bar{P}_{l} \Lambda_{i}}{\bar{C}}$

where $i$ refers to the different ${ }^{10}$ Be production pathways (n for neutron, $\mu$ s for slow muons, and $\mu$ f for fast muons); $\bar{P}_{l}$ is the mean basin-wide ${ }^{10}$ Be production rate, computed from the arithmetic mean of spallogenic and muogenic production rates using specific scalings for each production pathway as a function of elevation and latitude; $\Lambda_{i}$ are the attenuation lengths for each particle $\left(\Lambda_{\mathrm{n}}=160 \mathrm{~g} \mathrm{~cm}^{-2}, \Lambda_{\mu \mathrm{s}}=1,500 \mathrm{~g} \mathrm{~cm}^{-2} \text {, and } \Lambda_{\mu \mathrm{f}}=4,320 \mathrm{~g} \mathrm{~cm}^{-2}\right)^{52} ; \rho$ is the mean density of the eroded material $\left(2.7 \mathrm{~g} \mathrm{~cm}^{-3}\right)$; and $\bar{C}$ is the ${ }^{10} \mathrm{Be}$ concentration measured in the sediments sampled from the cores, after correction for radioactive decay (maximum correction of $4 \%$ for the oldest sample, $73.9 \mathrm{ka}$ ). $\bar{P}_{\imath}$ was calculated using the BASINGA GIS tool $^{36}$ and the Lal-Stone scaling model ${ }^{53}$. We used the following values as sea-level, high- 
1 latitude production rates: $P_{\mathrm{n}}=4.11 \pm 0.19$ atoms g-1 $\mathrm{a}^{1}, P_{\mu \mathrm{s}}=0.011 \pm 0.001$ atoms $\mathrm{g}^{-1} \mathrm{a}^{-1}$, and

$2 P_{\mu \mathrm{f}}=0.039 \pm 0.004$ atoms $\mathrm{g}^{-1} \mathrm{a}^{-1}$ (global mean derived from the CREp online calculator;

3 https://crep.otelo.univ-lorraine.fr/ $)^{52,54}$. All production rates are given in Supplementary

4 Tables 3 and 4 . All measured ${ }^{10} \mathrm{Be} /{ }^{9} \mathrm{Be}$ ratios were calibrated using the CEREGE STD11 in-

5 house normalization, which is similar to the KNSTD07 normalization and assumes a ${ }^{10} \mathrm{Be} /{ }^{9} \mathrm{Be}$ ratio of $(2.79 \pm 0.03) \times 10^{-11}$ for the SRM4325 standard material 55 .

Quartz-free areas (based on 1:250,000-scale French Geological Survey geological maps ${ }^{56,57}$ ) were excluded from the basin-averaged production rate calculations. Production rates were corrected for topographic shielding, ice cover, and changes in paleo-magnetic variations occurring during the integration time ${ }^{36}$. Topographic shielding factors were calculated using an ArcGIS toolbox ${ }^{58}$ that computes both self-shielding and shading. Ice cover was estimated independently for each sample, and production rates were considered null under the extent of the ice cover. Paleomagnetic changes were averaged over the $3 \mathrm{ka}$ preceding the age of the sample. We used paleomagnetic data from Muscheler et al. ${ }^{59}$ for samples dating to 0-60 ka and data from Valet et al. ${ }^{60}$ for older samples. Paleomagnetic correction factors ranged from 0.90 to 1.06.

\section{Integration time}

A crucial consideration in cosmogenic dating is the method's ability to detect changes in denudation rates. This mainly depends on the integration time, $T_{\mathrm{int}}$, which is the amount of time required to remove about $60 \mathrm{~cm}$ of bedrock, calculated as $T_{\mathrm{int}}=\Lambda /(\rho \varepsilon)$, where $\Lambda$ is the neutronic attenuation length $\left(\mathrm{g} \mathrm{cm}^{-2}\right), \rho$ the rock density $\left(\mathrm{g} \mathrm{cm}^{-3}\right)$ and $\varepsilon$ the denudation rate $\left(\mathrm{cm} \mathrm{a}^{-1}\right)^{12,61}$. To detect past changes, this integration time must be shorter than the timescale of denudation rate changes. In this dataset, the computed integration time ranges from 0.5 to $3.9 \mathrm{ka}$. 


\section{Impact of grain-size on $\mathrm{in}-\mathrm{situ}^{10} \mathrm{Be}$ concentration measurements}

Our previous study showed that, in modern Var sediments, both the 50-100 $\mu \mathrm{m}$ and

$100-250 \mu \mathrm{m}$ size fractions have similar ${ }^{10} \mathrm{Be}$ concentrations at the river outlet ${ }^{27}$. To verify that submarine processes did not induce a grain size-related bias, here we analyzed ${ }^{10} \mathrm{Be}$ concentrations in the same size fractions when the sample size was large enough 17 of 26 samples). ${ }^{10} \mathrm{Be}$ concentrations were compatible at the $2 \sigma$ level for both size fractions in all 17 samples, and the best-fit regression is statistically compatible with the 1:1 line (Extended Data Fig. 1). These results suggest that submarine turbidite dynamics do not induce a record bias. Consequently, we used the weighted mean ${ }^{10} \mathrm{Be}$ concentrations from both grain sizes to derive denudation rates (Supplementary Table 1).

\section{Sediment provenance}

We use $\varepsilon N d$ values measured in bulk sediments (finer than $63 \mu \mathrm{m}$ ) to trace sediment provenance across the catchment. Indeed, it was previously shown that the $\varepsilon \mathrm{Nd}$ signatures in cores ESSK08-CS01 and ESSK08-CS13 provide a reliable means to distinguish sediment contributions from glaciated and non-glaciated $\operatorname{areas}^{24}$ (Fig. 2c). Here we used the same methodology ${ }^{24}$ to complete the $\varepsilon N d$ record to the bottom of core ESSK08-CS13, i.e., from 50 to 74 ka (Supplementary Table 5). Prior to sample analysis, we removed carbonates, Fe-Mn oxyhydroxides, and organic compounds by successive leachings. The completed $\varepsilon \mathrm{Nd}$ record allows direct comparison with the ${ }^{10}$ Be data over the entire study period (Fig. 2c).

\section{Reference for Figure 1}

The bathymetric map was obtained from the EMODnet Bathymetry Consortium ${ }^{62}$. 


\section{DATA AVAILABILITY}

The datasets generated and analyzed during the current study are available in the ORDaR

Repository:

https://doi.org/10.24396/ORDAR-46 (Table S1 - Raw ${ }^{10}$ Be data),

https://doi.org/10.24396/ORDAR-47 (Table S2 - Core age models),

https://doi.org/10.24396/ORDAR-48 (Table S3 - $\varepsilon N d$ data),

https://doi.org/10.24396/ORDAR-49 (Table S4 - Denudation rates), https://doi.org/10.24396/ORDAR-50 (Table S5 - Glacial erosion rates), https://doi.org/10.24396/ORDAR-51 (Table S6 - Monte Carlo draws parameters).

\section{CODE AVAILABILITY}

The Matlab $\odot$ code used to determine glacial erosion rates is available upon request. Send an email to P.-H. Blard: blard@crpg.cnrs-nancy.fr

\section{REFERENCES}

51. Lefort, O. ESSDIV Cruise - RV Pourquoi pas ? IFREMER (2008). doi:10.17600/8030010

52. Braucher, R., Merchel, S., Borgomano, J. \& Bourlès, D. L. Production of cosmogenic radionuclides at great depth: A multi element approach. Earth Planet. Sci. Lett. 309, 1-9 (2011).

53. Stone, J. O. H. Air pressure and cosmogenic isotope production. J. Geophys. Res. Solid Earth 105, 23753-23759 (2000).

54. Martin, L. C. P. et al. The CREp program and the ICE-D production rate calibration database: A fully parameterizable and updated online tool to compute cosmic-ray exposure ages. Quat. Geochronol. 38, 25-49 (2017). 
1 55. Braucher, R. et al. Preparation of ASTER in-house 10Be/9Be standard solutions. Nucl. Instruments Methods Phys. Res. Sect. B Beam Interact. with Mater. Atoms 361, 335-340 (2015).

56. Kergkhove, C. \& Montjuvent, G. Carte géologique de la France à 1/250 000 - Gap. (BRGM, 1977).

57. Roure, J., Autran, A., Prost, A., Rossi, A. \& Rousset, C. Carte géologique de la France à 1/250 000 - Nice. (1976).

58. Codilean, A. T. Calculation of the cosmogenic nuclide production topographic shielding scaling factor for large areas using DEMs. Earth Surf. Process. Landforms 31, 785-794 (2006).

59. Muscheler, R., Beer, J., Kubik, P. W. \& Synal, H.-A. Geomagnetic field intensity during the last 60,000 years based on 10Be and 36Cl from the Summit ice cores and 14C. Quat. Sci. Rev. 24, 1849-1860 (2005).

60. Valet, J.-P., Meynadier, L. \& Guyodo, Y. Geomagnetic dipole strength and reversal rate over the past two million years. Nature 435, 802-805 (2005).

61. Lal, D. Cosmic ray labeling of erosion surfaces: in situ nuclide production rates and erosion models. Earth Planet. Sci. Lett. Elsevier Sci. Publ. B.V 104, 424-439 (1991).

62. EMODnet Bathymetry Consortium. EMODnet Digital Bathymetry (DTM). (2016). doi:10.12770/c7b53704-999d-4721-b1a3-04ec60c87238. 


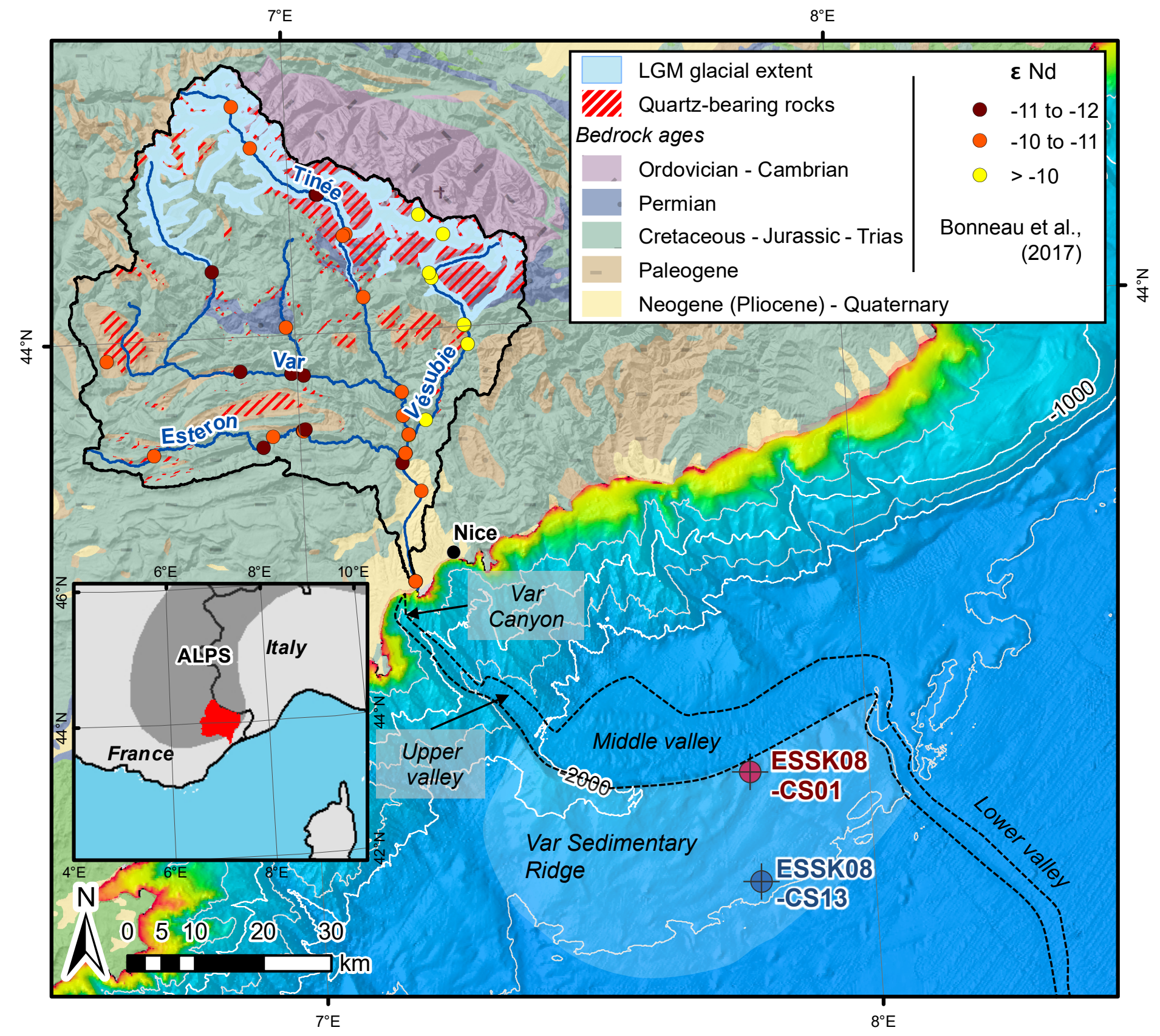




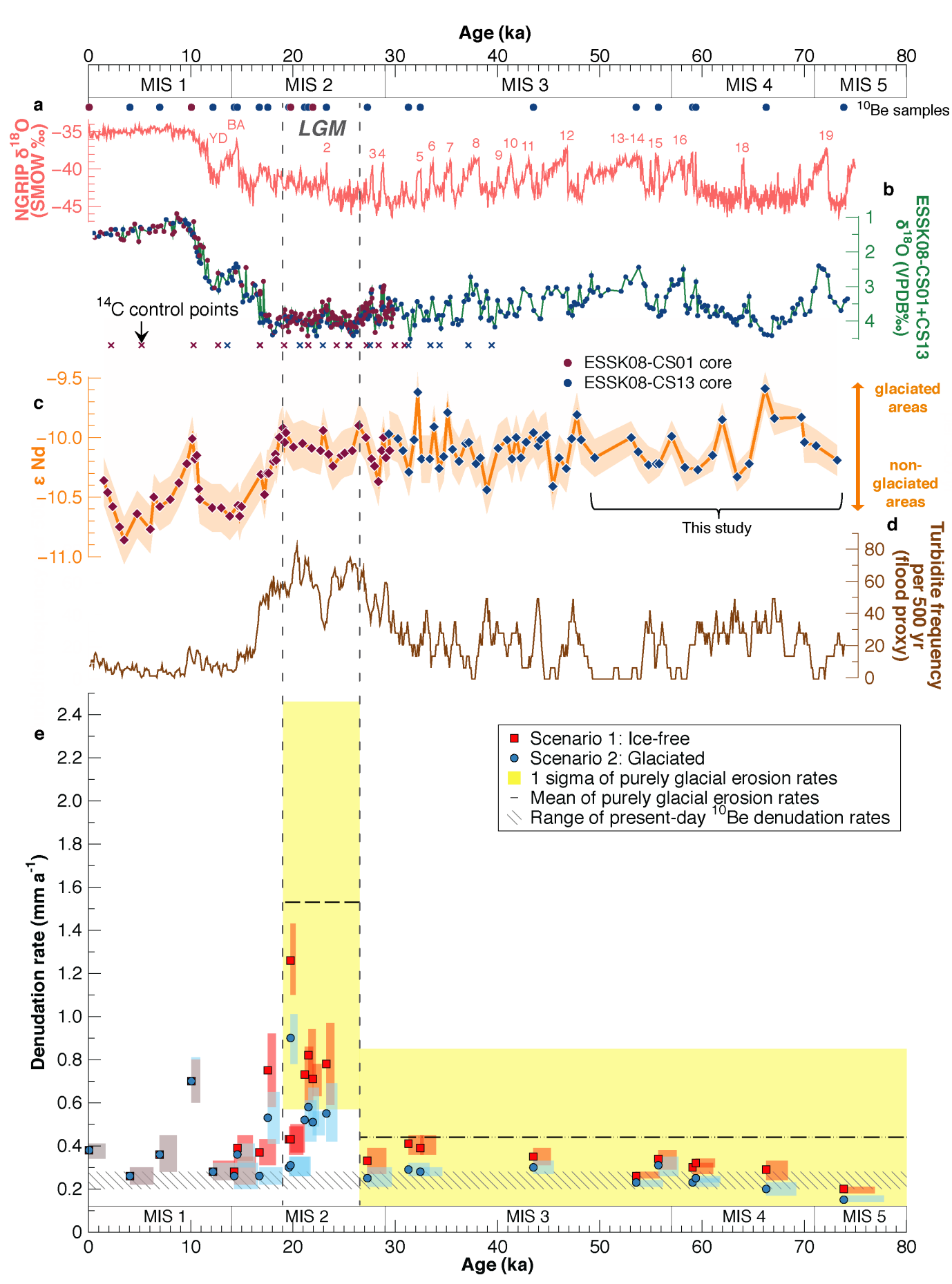




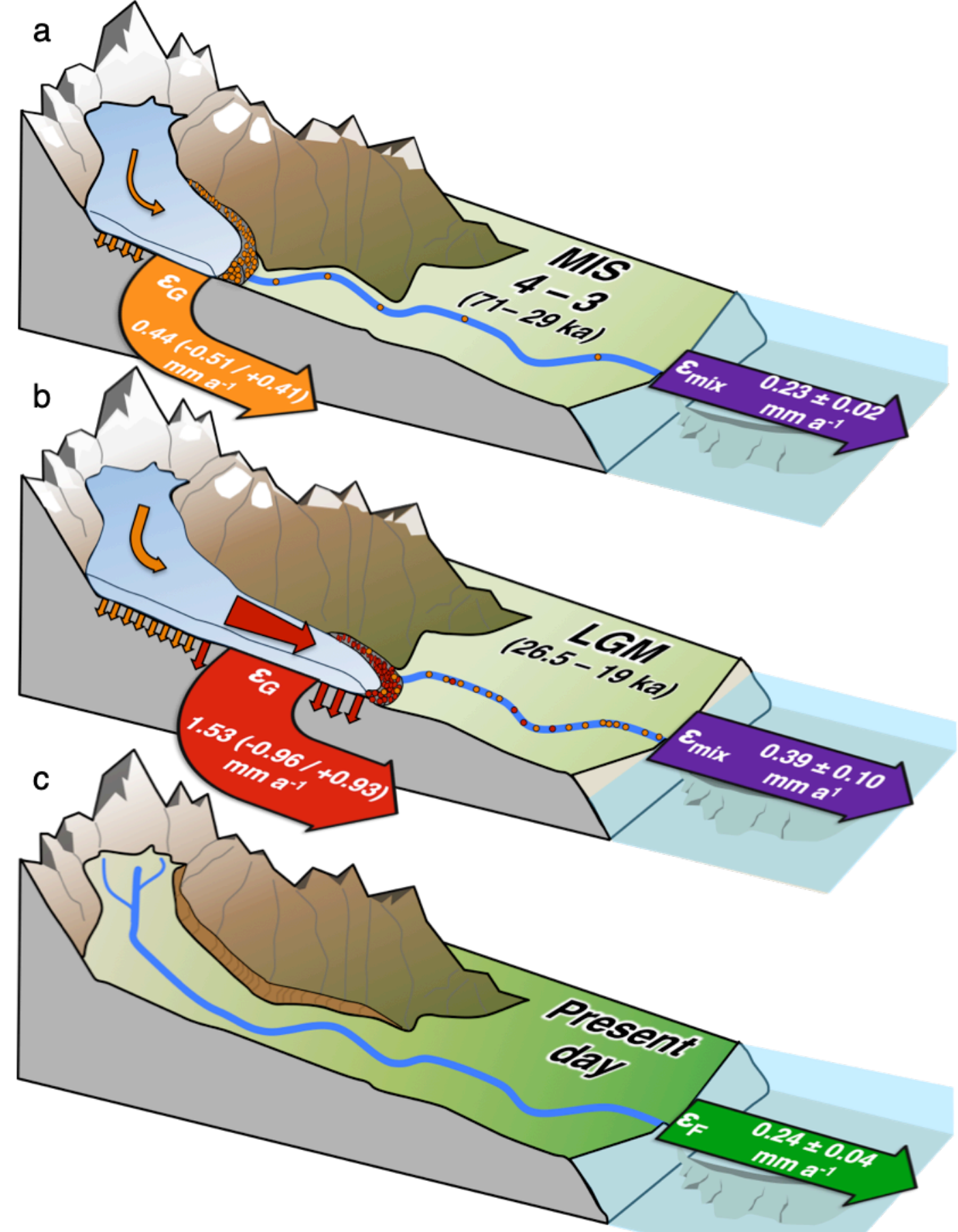




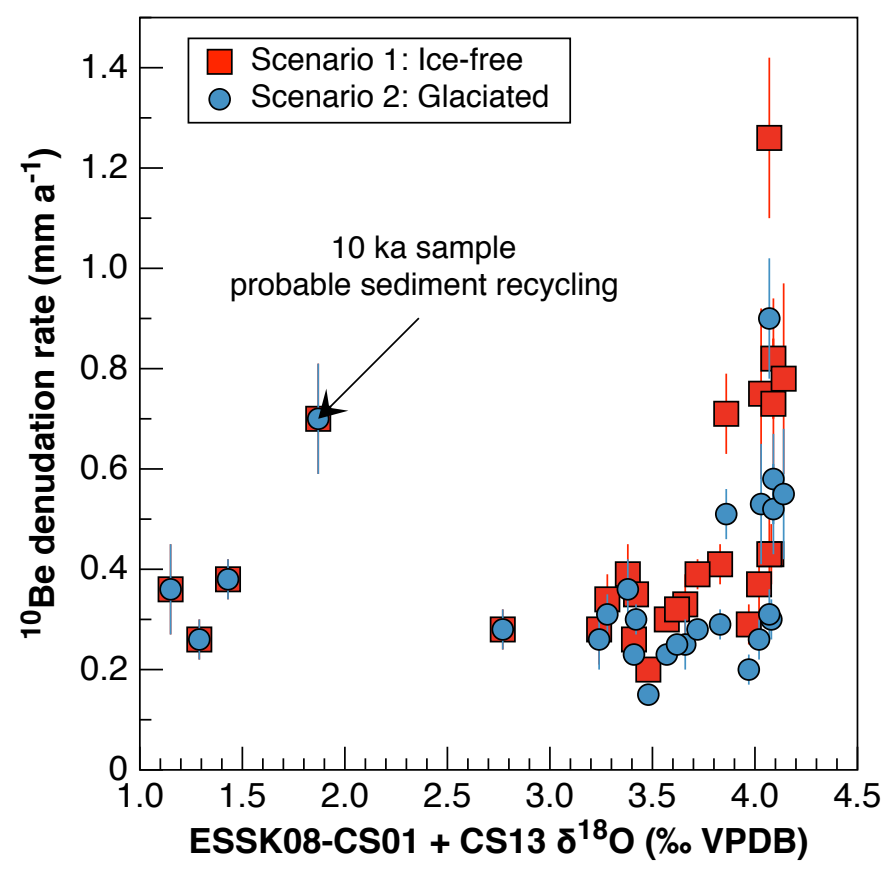

